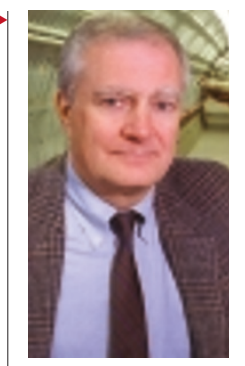

John Marburger thinks a US role in ITER "should be reconsidered". the United States to join," he says.

Japan and Canada have lobbied hard to get the Bush administration to give the project a second look. Canada, which joined the collaboration in 1997, is particularly keen on US participation, which it sees as lending credibility to its bid to host construction.

Fusion researchers are enthusiastic about participation in ITER - provided that additional resources are made available to pay for it. "I think the community is very excited about the possibility of rejoining ITER," says Richard Hazeltine, director of the Institute for Fusion Studies at the University of Texas at Austin. Hazeltine criticized ITER before the US withdrawal, but thinks that the new design addresses his concerns.

The United States still has a long way to go before it could rejoin the project, cautions Anne Davies, director of the Office of Fusion Energy Sciences at the energy department. "We're just at the beginning stages of considering what our position should be," she says. Congress and the administration must pledge their full support before US fusion researchers could resume participation, she adds.

www.iter.org

\title{
New-generation cars become old hat as US changes course
}

\section{Mark Schrope}

The Partnership for a New Generation of Vehicles (PNGV), a collaboration between the US government and industry to develop more efficient cars, is being replaced with a new programme called Freedom Cooperative Automotive Research, or Freedom CAR.

US energy secretary Spencer Abraham announced the change on 9 January at the Detroit Auto Show, saying that the aim is to "promote the development of hydrogen as a primary fuel for cars and trucks, as part of our effort to reduce American dependence on foreign oil". He added that the PNGV was not cost-effective and was not producing cars that were ready for the showroom.

Set up in 1993, the PNGV was strongly championed by then vice-president Al Gore. Its brief was to produce environmentally friendly prototype cars that were three times as fuel-efficient as those for sale at the time.

The programme included support for research into cars powered by hydrogen fuel cells. But the technology was not available to meet the 2004 deadline, and the PNGV turned to improving existing technologies.

Environmentalists are interpreting the announcement as a retreat from the Clinton administration's commitment to improving fuel economy in the short term. "This is a decision to coddle the US automotive industry, rather than hold it accountable for making real improvements in vehicle efficiency over the coming years," says John DeCicco of Environmental Defense, a New York-based pressure group.

Vernon Roan, director of the fuel-cell lab at the University of Florida in Gainesville and vice-chairman of the National Research Council's peer-review panel for the PNGV, says that the programme had many successes. He notes that the PNGV helped to build bridges between the government and the car industry, produced useful prototypes, and expedited the plans of Ford and General Motors to build and sell fuelefficient 'hybrid' vehicles that run on both petrol and battery power.

In its last review, the panel recommended substantial changes to the PNGV, and Roan says the new programme is consistent with these. "I think it is a good move," he says.

Although details of Freedom CAR have not been finalized, Mick Schwarz, who will lead Ford's participation in the programme, says that it may encourage the construction of infrastructure — including hydrogen filling stations. Schwarz says that he hopes the new programme's budget will match or exceed the $\$ 127$ million given to the PNGV this year. www.ta.doc.gov/pngv

\section{Bank wants money back from troubled chimp facility}

\section{Erika Check, Washington}

A controversial facility in New Mexico that houses chimpanzees for research is facing a serious threat to its survival.

The Coulston Foundation's facility at Alamogordo has weathered years of financial problems, regulatory troubles and animal-rights protests. But now a New Mexico bank has filed a foreclosure lawsuit against the foundation, which houses about 250 chimps. The bank alleges that Frederick Coulston and his foundation have defaulted on over $\$ 1.16$ million in loan repayments.

It is unclear how the foundation will deal with the lawsuit. A representative declined to comment, referring enquires to Coulston's lawyer, who did not return telephone calls.

But Joe Bielitzki, a member of the board of the Scientists Center for Animal Welfare (SCAW), a non-profit group that supports animal research and promotes the humane treatment of research animals, says that researchers are concerned about what will happen to the chimps if the foundation shuts down. "Everybody assumes that the National
Institutes of Health or somebody would pick up the ball and run with it, but the question is who has responsibility for these animals," he says. "It's a really sticky, ugly situation."

Over the past three years, the foundation has lost all of its funding from the National Institutes of Health (NIH). Last year, the NIH's National Center for Research Resources (NCRR) removed the chimps from Coulston's responsibility — although they are still held in the same compound at Alamogordo. In 1999, the NIH decided against renewing two other grants to Coulston.

In July, the US Department of Agriculture alleged that the foundation had violated the Animal Welfare Act before the deaths of two chimps. In October, the Food and Drug Administration refused to grant permits for new experiments by the foundation.

The foundation has also long been a target of animal-rights protesters. Last September, the Animal Liberation Front claimed responsibility for a fire at Coulston's facility.

Space for chimps in the United States is limited, and the issue of their long-term care

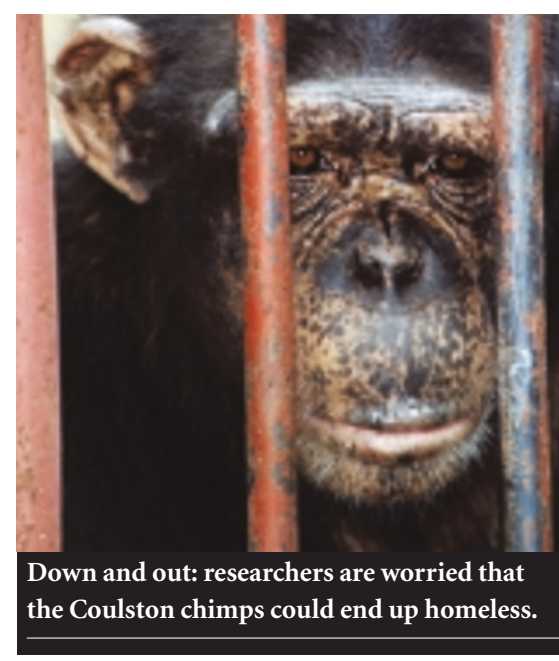

is problematic. Chimps are now rarely used in research, and this year the NCRR will award a \$5-million contract for the construction of a 'sanctuary' to house about 200 retired chimps. However, this will not be ready for several years, and the NIH has already allocated animals to it. 